\title{
In'n vreemde wêreld gee God jou leiding hoe om te leef en dui Hy die koers aan waarheen jy op pad is
}

\begin{tabular}{|c|c|}
\hline \multicolumn{2}{|c|}{$\begin{array}{l}\text { Book Title: } \\
\text { Gereed vir die Wederkoms? } \\
\text { 'n Bybelstudie oor } 1 \text { en } 2 \\
\text { Petrus }\end{array}$} \\
\hline \multicolumn{2}{|l|}{ Book Cover: } \\
\hline \multicolumn{2}{|c|}{$\begin{array}{l}\text { GEREED virdie } \\
\text { WEDERKOMS? }\end{array}$} \\
\hline \multicolumn{2}{|c|}{ 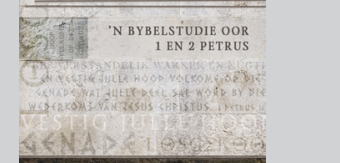 } \\
\hline \multicolumn{2}{|c|}{ JOHAN SMIT } \\
\hline \multicolumn{2}{|l|}{$\begin{array}{l}\text { Author: } \\
\text { Johan Smit }\end{array}$} \\
\hline \multicolumn{2}{|c|}{$\begin{array}{l}\text { ISBN: } \\
\text { 987-1-4316-1379-3 }\end{array}$} \\
\hline $\begin{array}{l}\text { Publisher: } \\
\text { Christelike Uit } \\
\text { Maatskappy, } 2 \\
\text { *Book price at ti }\end{array}$ & $\begin{array}{l}\text { sewers } \\
\text { 015, R129.95* } \\
\text { me of review }\end{array}$ \\
\hline \multicolumn{2}{|c|}{$\begin{array}{l}\text { Review Title: } \\
\text { In 'n vreemde wêreld gee } \\
\text { God jou leiding hoe om te } \\
\text { leef en dui Hy die koers aan } \\
\text { waarheen jy op pad is }\end{array}$} \\
\hline \multicolumn{2}{|l|}{ Reviewer: } \\
\hline \multicolumn{2}{|c|}{$\begin{array}{l}\text { Affiliation: } \\
{ }^{1} \text { Reformed Church, } \\
\text { Potchefstroom-East, South } \\
\text { Africa }\end{array}$} \\
\hline \multicolumn{2}{|c|}{$\begin{array}{l}\text { Corresponding author: } \\
\text { Piet Venter, } \\
\text { dspietventer@oosdoppers. } \\
\text { co.za }\end{array}$} \\
\hline \multicolumn{2}{|c|}{$\begin{array}{l}\text { How to cite this book review: } \\
\text { Venter, P., 2016, 'In 'n } \\
\text { vreemde wêreld gee God jou } \\
\text { leiding hoe om te leef en dui } \\
\text { Hy die koers aan waarheen jy } \\
\text { op pad is', In die Skriflig 50(2), } \\
\text { a2137. http://dx.doi. } \\
\text { org/10.4102/ids.v50i2.2137 }\end{array}$} \\
\hline \multicolumn{2}{|l|}{ Read online: } \\
\hline 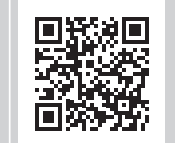 & $\begin{array}{l}\text { Scan this QR } \\
\text { code with your } \\
\text { smart phone or } \\
\text { mobile device } \\
\text { to read online. }\end{array}$ \\
\hline
\end{tabular}

As vreemdelinge' (1 Pet 1:1) op reis deur hierdie wêreld het ons die lig en leiding van die Here dringend nodig. Die Here gee hierdie lig op en koers vir ons lewenspad op baie besondere manier in 1 en 2 Petrus. Johan Smit slaag op uitmuntende wyse daarin om hierdie lig en leiding uit die twee briewe op baie praktiese en eenvoudige wyse in die lewe van die gelowige te laat spreek.

Baie gelowiges fokus in hulle lewe slegs op die uitdagings wat die lewe ons van dag tot dag bied en verloor in die proses perspektief op die wederkoms van die Here. Dit is dus nodig om hierdie perspektief op die wederkoms sterk te beklemtoon sodat ons verstaan wat ons roeping op aarde is in die lig van die feit dat ons ons voorberei vir die lewe op die nuwe aarde.

Die skrywer gee ter inleiding eers 'n kompakte en eenvoudige beskrywing van die kultuurhistoriese agtergrond (kanoniek) van die twee briewe. Die inhoud van die hoofstukke van 1 en 2 Petrus word in 25 kompakte eenhede verdeel waarvan die inhoud van elke eenheid met ' $n$ baie treffende en aktuele tema voorsien word. Temas soos 'Die onberekenbare prys', 'Onverdiende lyding', 'Die Christenvrou' en 'Onder nuwe bestuur' prikkel die leser se belangstelling en laat jou lekker lees aan die inhoud.

Die Bybelteks van elke eenheid word volledig vir die leser gegee sodat die leser nie nodig het om 'n Bybel byderhand te hê nie. Daarna word die kernaspekte van die leeseenheid weergee en eenvoudig in enkele paragrawe bespreek. Aan die einde van elke eenheid word besprekingsvrae gegee aan die hand waarvan die leser oor die inhoud kan besin en persoonlik kan toepas. Daar word by die besprekings-vrae ook ruim plek voorsien waar die leser aantekeninge kan maak. Hierdie formaat maak dit vir die leser moontlik om die inhoud te verwerk en toe te pas in eie lewensomstandighede.

Die briewe van Petrus handel oor baie praktiese lewensvraagstukke. Hy spreek die persoonlike geloofslewe en groei van die gelowige aan sowel as jou lewe as deel van die kerk van die Here. Die roeping van die gelowige in die wêreld teenoor ongelowiges, as landsburger, as werknemer of werkgewer en as huweliksmaat word bespreek en prakties toegepas. Die uiters belangrike tema met betrekking tot die doel van lyding in die gelowige se lewe word op 'n positiewe manier aangespreek. Die nodige waarskuwing teen die leuens van dwaalleraars word aktueel toegepas en dan word die oog van die gelowiges gevestig op die wederkoms van Jesus Christus en die gebeure wat dit vooraf sal gaan.

Die skrywer slaag daarin om die leser met die temas wat hy bespreek en die wyse waarop hy dit aanbied saam te neem op hierdie reis deur die wêreld in die lig van God se Woord en met die leiding wat Hy ons bied. Hy maak die leser opnuut bewus van die einddoel van alles naamlik die wederkoms van Christus en die betekenis daarvan vir die leser.

Daar is moeilik verklaarbare tekste in 2 Petrus 2 met betrekking tot die engele of hemelwesens en aanhalings uit die Ou Testament wat toegepas word op die situasie van die oorspronklike lesers se lewe. Die skrywer erken eerlik dat dit moeilike tekste is en gee op verstaanbare wyse die verskillende verklaringsmoontlikhede. Hy kies dan 'n verklaringsmoontlikheid waarmee hy die saak op die dwaalleer en leuens van die moderne tyd van toepassing maak.

Die boek is gerig op die ernstige Bybelstudent wat nie net vinnig wil lees en hoor nie maar ernstig die dieper waarhede van die Here se boodskap in 1 en 2 Petrus self wil ontdek, oordink en toepas op vandag. Tog is die teks maklik en lekker leesbaar geskryf en gee vir die moderne gelowige, wie die wêreld al hoe meer lewensvreemd vind, kosbare insig oor hoe God wil dat gelowiges vandag moet lewe in die lig van die wederkoms van Christus. 